\title{
PENGEMBANGAN E-MODUL BERBASIS LITERASI SAINS MATERI ORGAN GERAK HEWAN DAN MANUSIA KELAS V SD
}

\author{
Rizan Dwi Atmaji, Ika Maryani \\ Universitas Ahmad Dahlan \\ e-mail: rizandwia@gmail.com
}

\begin{abstract}
. This type of research is development research with the ADDIE model. This research begins with analysis, design, development, implementation, and evaluation. The subjects in this study were media expert validators, material experts, learning experts, students, and teachers. The results of the development in the form of science-based emodules are in the form of evaluations from expert validators and trials of students and teachers. The assessment of media experts received a score of 92.85 with the category "Very Worthy. Material experts received a rating of 92.85 in the "Very Worthy" category. The results of the assessment of learning experts get a value of 73.21 with the category "Eligible". the assessment of small-scale trials conducted by students gets a score of 95 with the category "Very Worthy" and the assessment of the teacher gets a score of 95 with the category "Very Worthy". The large-scale trials conducted by students got a score of 96.6 with the category "Very Worthy" and the assessment of the teacher received a score of 97.08 with the category "Very Worthy". Based on the results of the research obtained, science-based e-modules are very feasible to be used in the learning process at school.
\end{abstract}

Keywords: E-modul, IPA, Literasi Sains

\begin{abstract}
ABSTRAK
Penelitian ini bertujuan untuk mengetahui langkah-langkah pengembangan dan kelayakan e-modul berbasis literasi sains. Jenis penelitian ini merupakan penelitian pengembangan dengan model ADDIE. Penelitian ini diawali dari analisis, desain, pengembangan, implementasi, dan evaluasi. Subjek dalam penelitian ini adalah validator ahli media, ahli materi, ahli pembelajaran, peserta didik, dan guru. Hasil pengembangan berupa e-modul berbasis literasi sains yang berupa penilaian dari validator ahli dan uji coba terhadap peserta didik dan guru. Penilaian ahli media mendapatkan nilai 92,85 dengan kategori "Sangat Layak. Ahli materi mendapatkan penilaian 92,85 dengan kategori "Sangat Layak". Hasil Penilaian ahli pembelajaran mendapatkan nilai 73,21 dengan kategori "Layak". penilaian dari uji coba skala kecil yang dilakukan oleh peserta didik mendapatkan nilai 95 dengan kategori "Sangat Layak" dan penilaian dari guru mendapatkan nilai 95 dengan kategori "Sangat Layak". Uji coba skala besar yang dilakukan oleh peserta didik mendapatkan nilai 96,6 dengan kategori "Sangat Layak" dan penilaian dari guru mendapatkan nilai 97,08 dengan kategori "Sangat Layak". Berdasarkan hasil penelitian yang didapatkan maka e-modul berbasis literasi sains sangat layak untuk digunakan dalam proses pembelajaran di sekolah.
\end{abstract}

Kata kunci: E-modul, IPA, Literasi Sains 


\section{PENDAHULUAN}

Pembelajaran Ilmu Pengetahuan Alam (IPA) merupakan salah satu pelajaran yang wajib dipelajari di jenjang pendidikan, salah satunya jenjang Sekolah Dasar (SD). Pembelajaran IPA merupakan ilmu pengetahuan yang mempelajari tentang seluruh peristiwa yang ada di sekitar. Pembelajaran IPA penting untuk dipelajari karena pembelajaran IPA memberikan kesempatan kepada peserta didik untuk berpikir kritis. Pembelajaran IPA penting untuk dipelajari di SD disamping sebagai mata pelajaran yang dijadikan mata pelajaran yang diujikan dalam ujian nasional (UN). Menurut Eviani, dkk (2014:3) pembelajaran IPA memiliki tiga aspek yang diutamakan yaitu (1) proses; (2) sikap; dan (3) produk. Melalui pembelajaran IPA peserta didik diharapkan untuk dapat mengembangkan dan memahami konsep-konsep IPA yang dapat bermanfaat yang dapat diterapkan dalam kehidupannya. Selain itu melalui pembelajaran IPA peserta didik diharapkan dapat mengembangkan rasa ingin tahu di setiap kegiatan pembelajaran. Selain itu melalui proses pembelajaran IPA harus menekankan belajarnya peserta didik tidak berpusat terhadap guru melainkan berpusat terhadap peserta didik. Melalui proses pembelajaran itu peserta didik dapat lebih meningkat rasa ingin tahu, sehingga dapat muncul kemampuan berpikir kritis dari peserta didik. Kemampuan berpikir kritis peserta didik dalam pembelajaran IPA diperlukan untuk menggali potensi dan pengetahuan peserta didik.

Dalam proses pembelajaran IPA di SD ditemukan berbagai permasalahan yang terjadi dilapangan. Permasalahan yang ditemukan diantaranya tidak sedikit peserta didik yang kurang termotivasi dalam belajar. Dari hal tersebut juga berpengaruh terhadap prestasi belajar peserta didik yang mendapatkan nilai dibawah KKM. Selain itu juga peserta didik juga merasakan jenuh mengikuti proses pembelajaran yang hanya berpusat kepada guru. Guru dalam proses pembelajaran belum memaksimalkan penggunaan media dalam pembelajaran. Serta penggunaan bahan ajar berbentuk modul juga belum dimaksimalkan penggunaannya dalam pembelajaran. Bahan ajar modul penting untuk digunakan agar peserta didik dapat belajar secara mandiri. Menurut Setiawan (2017) menyatakan bahwa bahan ajar yang dikembangkan untuk membantu peserta didik belajar secara mandiri.

Mulai tahun 2013 pemerintah mempunyai kebijakan terkait pergantian Kuikulum Tingkat Satuan Pendidikan (KTSP) berubah pada penerapan Kurikulum 2013. Pada tahun 2013 pemerintah memulai mengujicobakan penerapan kurikulum 2013 di beberapa sekolah. Salah satu jenjang sekolah yang mengujicobakan pergantian kurikulum ini adalah Sekolah Dasar (SD). Menurut Hastuti (2014:171) menyatakan bahwa dalam kurikulum 2013 jenjang SD kegiatan pembelajaran tematik terpadu menerapkan pendekatan saintifik. Pendekatan saintifik dalam pembelajaran untuk lebih mengaktifkan dan menumbuhkan kreatifitas peserta didik. Salah satu hal yang ditekankan dalam kurikulum 2013 ini adalah penumbuhan budaya literasi. Dalam implementasi kurikulum 2013 diharapkan peserta didik memiliki karakter literasi yang baik. Dengan membaca peserta didik akan mendapatkan banyak pengetahuan baru yang belum dimengerti. Gerakan budaya literasi sains ini harus ditanamkan sejak di jenjang SD. Kegiatan literasi dapat dilakukan oleh siapa saja, dimana saja, dan kapan saja. Apalagi di era zaman yang perkembangan teknologinya semakin cepat. Akses manusia untuk mendapatkan informasi atau pengetahuan baru lebih mudah dan cepat.

Menurut International Council of Associations for Science Education (ICASE) (dalam Sudarisman, 2015:30) menyatakan bahwa literasi perlu dikuasai peserta didik. Agar peserta didik mampu hidup secara produktif dan memperoleh kualitas hidup terbaik sesuai dengan tujuan sains. Kegiatan literasi dalam pembelajaran abad 21 sangat penting 
untuk dipelajari. Salah satu literasi yang harus dimiliki oleh peserta didik dalam abad 21 ini adalah literasi sains. Melalui literasi sains peserta didik diharapkkan dapat menyesuaikan perkembangan teknologi yang semakin canggih. Literasi sains juga dapat menjadi ciri kualitas dari pendidikan di Indonesia dimata dunia. Literasi sains menekankan kemampuan dalam memahami prinsip-prisip, proses-proses dasar, dan penerapan dalam kehidupan sehari-hari (Astuti, 2016).

\section{METODE PENELITIAN}

Penelitian ini menggunakan jenis peneletian dan pengembangan dengan model penelitian menggunakan ADDIE (Analysis, Design, Development, Implementation, Evaluation). Subjek penelitian ini adalah ahli media, ahli materi, ahli pembelajaran, peserta didik dan guru. Penelitian yang digunakan menggunakan jenis data kuantitatif dan kualitatif. Instrument pengumpulan data dalam penelitian ini adalah angket penilaian kelayakan e-modul yang meliputi validador ahli media, ahli materi, dan ahli pembelajaran. Serta angket guru dan peserta didik untuk uji penggunaan e-modul. Penelitian pengembangan ini menggunakan teknik analisis data deskriptif kualitatif dengan mengubah penilaian dalam bentuk kualitatif, selanjutnya data kuantitatif dihitung skor rataratanya dengan minimal skala penilaian dengan skor 50 dengan kategori layak.

\section{HASIL DAN PEMBAHASAN}

\section{Langkah-langkah Pengembangan}

Langkah dalam penelitian yang dilakukan diawali dari tahap analisis yang didapatkan dengan cara observasi menganalisis materi dan kebutuhan peserta didik dalam proses pembelajaran IPA kelas V SD N Bendungan 4. Dari hasil observasi didapatkan permasalahan berupa materi yang digunakan dalam pembelajaran menggunakan buku yang telah disediakan sekolah, belum memaksimalkan penggunaan bahan ajar lain untuk menambah wawasan peserta didik. Serta dari kebutuhan peserta didik terkait penggunaan media dalam proses pembelajaran, namun pada saat observasi belum memaksimalkan penggunaan media pembelajaran lain selain buku. Setelah mendapatkan permasalahan langkah selanjutnya tahap desain produk yang akan dibuat. Bahan-bahan materi yang akan disampaikan dikumpulkan yang meliputi materi, gambar, video, maupun soal evaluasi.

Langkah selanjutnya yaitu tahapa pengembangan e-modul dengan cara uji kelayakan terhadap ahli media, ahli materi, dan ahli pembelajaran. Revisi produk sebelum e-modul dijicobakan berdasarkan saran dari validator ahli. Setelah direvisi selanjutnya yaitu tahap implementasi produk di sekolah dengan uji coba produk skala kecil, skala besar, serta penilaian dari guru. Langkahb terakhir yang dilakukan adalah evaluasi dari pengembangan e-modul berdasarkan saran dari validator, serta dalam uji di sekolah.

2. Analisis Kelayakan E-Modul

Produk awal e-modul berbasis literasi sains, sebelum digunakan divalidasikan kepada validator ahli media, ahli materi, dan ahli pembelajaran. Validasi yang dilakukan oleh ahli media mendapatkan skor 92,85 dengan kategori sangat layak. validasi ahli materi mendapatkan skor 92,85 dengan kategori sangat layak. Serta validasi ahli pembelajaran mendapatkan skor 73,21 dengan kategori layak. Dari hasil validasi ketiga ahli setelah ditambah jadi satu didapatkan skor rata-rata 86,30, dengan kategori sangat layak.

3. Analisis Data

a. Analisis Data Kuantitatif

Tabel 1. Data Kuantitatif Hasil Ahli

No. Penilaian Skor Kategori




\begin{tabular}{cccc} 
1. & Ahli Media & 92,85 & Sangat Layak \\
\hline 2. & Ahli Materi & 92,85 & Sangat Layak \\
\hline 3. & Ahli Pembelajaran & 73,21 & Layak \\
\hline & Jumlah & 258,91 & \\
\hline & Rata -rata & 86,30 & Sangat Layak
\end{tabular}

Berdasarkan hasil perhitungan tersebut maka didapatkan hasil skor ratarata penilaian ahli yaitu 86,30, dan masuk kategori "Sangat Layak". Dan emodul yang dikembangkan layak digunakan sebagai bahan ajar yang digunakan dalam pembelajaran.

Tabel 2. Data Kuantitatif Hasil Penilaian Guru dan Peserta didik Pada Uji Coba Skala Kecil

\begin{tabular}{cccc} 
No. & Penilaian & Skor & Kategori \\
\hline 1. & Angket Guru & 95 & Sangat Layak \\
\hline 2. & Angket Peserta didik & 95 & Sangat Layak \\
\hline & Jumlah & 190 & \\
\hline & Rata -rata & 95 & Sangat Layak
\end{tabular}

Dari data di atas diketahui skor yang diperoleh dari penialaian guru dan siswa terhadap pengembangan e-modul adalah termasuk dalam kategori sangat layak dan layak digunakan sebagai bahan ajar sebagai penunjang pembelajaran.

Tabel 3. Data Kuantitatif Hasil Penilaian Guru dan Peserta didik Pada Uji Coba Pemakaian

\begin{tabular}{cccc} 
No. & Penilaian & Skor & Kategori \\
\cline { 1 - 2 } 1. & Angket Guru & 96,6 & Sangat Layak \\
\hline 2. & Angket Peserta didik & 97,08 & Sangat Layak \\
\hline & Jumlah & 193,68 & \\
\hline & Rata -rata & 96,84 & Sangat Layak
\end{tabular}

Dari data di atas diketahui skor yang diperoleh dari penialaian guru dan siswa terhadap pengembangan e-modul adalah termasuk dalam kategori sangat layak dan layak digunakan sebagai bahan ajar sebagai penunjang pembelajaran. Literasi sains yang muncul pada waktu implementasi produk yaitu peserta didik dan guru bertanya jawab pada saat pembelajaran. Peserta didik menjawab pertanyaan dengan mencontohkan kejadian yang dialaminya serta yang ditemuinya dalam kehidupan sehari-hari. Aspek ini sebagai bentuk sains sebagai batang tubuh dengan indikator pembelajaran proses bertanya untuk mengingat informasi yang diperoleh peserta didik. Aspek lain yang ditemukan sebelum menggunkan modul peserta didik diwajibkan membaca petunjuk penggunaan agar memudahkan menggunakannya. Aspek ini sebagai bentuk sains sebagai sains sebagai jalan untuk investigasi dengan indikator panduan guru mengajarkan peserta didik melalui penggunaan modul. Secara keseluruhan hasil data kuantitatif dari validasi ahli, uji coba produk skala kecil dan uji coba skala besar adalah sebagai berikut.

Tabel 4. Hasil Data Kuantitatif Keseluruhan
No
Penilaian
Skor
Kategori 


\begin{tabular}{|c|c|c|c|}
\hline 1 & Ahli Media & 92,85 & Sangat Layak \\
\hline 2 & Ahli Materi & 92,85 & Sangat Layak \\
\hline 3 & Ahli Pembelajaran & 73,21 & Layak \\
\hline & \multicolumn{2}{|c|}{ Uji Coba Skala Kecil } & \\
\hline 1 & Angket Guru & 95 & Sangat Layak \\
\hline 2 & Angket Peserta didik & 95 & Sangat Layak \\
\hline & \multicolumn{2}{|c|}{ Uji Coba Skala Besar } & \\
\hline 1 & Angket Guru & 96,6 & Sangat Layak \\
\hline 2 & Angket Peserta didik & 97,08 & Sangat Layak \\
\hline & Jumlah & 642,59 & \\
\hline & Rata-rata & 91,80 & Sangat Layak \\
\hline
\end{tabular}

Tabel tersebut menunjukan bahwa skor rata-rata dari penilaian yang sudah diakumulasi dan dirata-rata menunjukan skor 91,80, dan masuk kedalam kategori sangat layak.

b. Analisis Data Kualitatif

Analisis data dari ahli media mendapatkan saran media yaitu (1) pencantuman sumber pengambilan video; (2) penomoran halaman harus konsisten; (3) gambar di bagian cover belakang lebih ditransparankan; dan (4) penambahan petunjuk penggunaan agar lebih mudah digunakan.. Kemudian analisis data dari ahli materi mendapatkan saran yaitu dalam materi dimasukan unsur religious dan aturan penggunaan agar memudahkan dalam penggunaan. Analisis data dari ahli pembelajaran mendapatkan saran untuk indikator disesuaikan dengan KD. Sedangkan analisis data dari uji coba produk didapatkan saran yaitu, materi agar dapat dikembangkan untuk materi lain, tidak hanya materi organ gerak hewan dan manusia.

4. Kajian Produk Akhir

Perkembangan teknologi yang semakin pesat perubahan modul dari yang cetak ke bentuk digital sangat dimungkinkan. Era digital saat ini e-modul penting dikembangkan terlebih lagi saat sudah banyak ditemui. Namun e-modul yang dikembangkan sebagian hanya berisi teks dan gambar. Dalam pengembangan e-modul harus ada inovasi lain yang didalamnya dapat membuat peserta didik belajar yang tidak hanya membaca teks namun juga dapat belajar materi dari video, menjawab pertanyaan secara langsung. Emodul yang dikembangkan ini tidak hanya terdapat teks maupun gambar, namun juga terdapat video yang terkait pembelajaran. Serta juga terdapat soal evaluasi yang dapat dikerjakan secara langsung oleh peserta didik dalam e-modul.E-modul yang dikembangakan berbasis literasi sains. Pengembangan e-modul berbasis literasi sains perlu dikembangkan dikarenakan penguasaan literasi sains penting dalam kemajuan sebuah pendidikan.

Aspek literasi sains dalam racangan e-modul terdapat didalam sampul depan dan sampul belakang, aspek ini sebagai bentuk sains sebagai batang tubuh. Literasi sains disajikan dalam bentuk gambar hewan, tumbuhan, serta kerangka manusia yang nyata dalam kehidupan dan dapat ditemui dalam keseharian peserta didik, spek ini juga merupakan sains sebagai batang tubuh. Materi hewan yang disajikan dalam modul ada dan dapat ditemui dalam kehidupan sehari-hari peserta didik, aspek ini sebagai sains sebagai batang tubuh. Aspek lain yang muncul dari literasi sains yaitu didalam materi yang memuat pertanyan untuk peserta didik berdiskusi dengan guru dan dapat mencontohkan dalam kehidupan nyata. Serta aspek literasi sains yang disajikan yang disajikan yaitu seperti perintah Ayo Bacalah dan Ayo Kerjakan, sebagai aspek sains 
sebagai jalan investigasi. Pemberian soal untuk berdiskusi dalam soal evaluasi pembelajaran 2, sebagai bentuk sains sebagai cara berpikir.

5. Pembahasan

Produk yang dikembangkan telah diuji cobakan ke sekolah untuk mendapat penilaian dari e-modul yang dikembangkan. Uji coba yang dilakukan dalam skala kecil maupun skala besar. Penilaian dalam uji coba dilakukan pretes dan postest dilakuan baik dalam uji coba skala kecil maupun skala besar. Pretest dilakukan sebelum peserta didik belajar menggunakan e-modul yang dikembangkan. Sedangkan postes dilakuan setelah peserta didik menggunakan e-modul. Uji coba skala kecil dilakukan terhadap 10 orang peserta didik yang dipilih secara acak. Uji pretest dan postest untuk mengetahui hasil belajar peserta didik sebelum dan setelah menggunkan e-modul. Hasil pretes uji coba skala kecil didapatkan hasil rata-rata nilai 66. Sedangkan hasil postes didik sebanyak 30 orang. Pretes juga dilakukan dalam uji coba skala kecil dengan nilai ratarata 76 , serta postes dengan rata-rata nilai 97,37.

Berdasarkan hasil tersebut terlihat perbedaan serta peningkatan nilai yang didapatkan dari rata-rata dari pretes maupun postes. Peningkatan nilai dari uji coba skala kecil maupun besar, dapat disimpulkan bahwa hasil belajar peserta didik meningkat. Hasil belajar yang meningkat baik dari uji coba dapat disimpulkan bahwa emodul yang dikembangkan dapat meningkatkan hasil belajar mata pelajaran ipa materi organ gerak hewan dan manusia. Berdasarkan penelitian yang perneh dilakukan oleh Theresia, dkk (2015:39) menyatakan bahwa kefektifan bahan ajar berorientasi literasi sains adalah dapat meningkatkan hasil belajar peserta didik. Serta literasi sains yang muncul pada waktu implementasi produk yaitu peserta didik dan guru bertanya jawab pada saat pembelajaran. Peserta didik menjawab pertanyaan dengan mencontohkan kejadian yang dialaminya serta yang ditemuinya dalam kehidupan sehari-hari.

\section{SIMPULANI}

Pengembangan e-modul berbasis literasi sains cara pembuatannya berdasarkan tahapan penelitian pengembanganmenggunakan model ADDIE. Tahapan pertama yaitu tahap analisis mencari permasalahan dan potensi yang ada di SD. Selanjutnya tahap desain pengumpulan bahan-bahan yang akan dimasukan dan disesuaikan dengan materi. Setelah semua bahan terkumpul tahap selanjutnya adalah pengembangan dari produk yang sudah jadi dan dilakukan validasi oleh ahli media, ahli materi, dan ahli pembelajaran. Langkah selanjutnya yaitu tahap implementasi uji coba di lapangan baik dalam skala kecil maupun skala besar. Serta sebagai langkah terakhir yaitu evaluasi dari pengembangan produk berdasarkan masukan dari validasi ahli maupun dari masukan pada waktu uji coba produk dilapangan.

Berdasarkan hasil penelitian dan pengembangan yang didapat penilaian oleh ahli media mendapat skor penilaian 92,85 dengan kategori "Sangat Layak". Penilaian yang dilakukan oleh ahli materi mendapatkan skor penilaian 92,85 dengan kategori "Sangat Layak". Kemudian penilaian oleh ahli pembelajaran didapatkan hasil skor penilaian sejumlah 73,21 dengan ketegori "Layak". Hasil validasi yang dilakukan oleh peserta didik juga didapatkan hasil penilaian uji coba terbatas mendapatkan skor 95 dengan kategori "Sangat Layak". Sementara hasil penilaian yang dilakukan oleh guru mendapatkan skor penilaian 95 dengan kategori "Sangat Layak". Selanjutnya diuji cobakan dalam skala besar terhadap peserta didik didapat skor 97,08 dengan kategori "Sangat Layak". serta penilaia yang dilakukan oleh guru didapatkan hasil skor 96,6 dengan kategori "Sangat Layak". 


\section{DAFTAR PUSTAKA}

Astuti, Yani K. 2016. Literasi Sains Dalam Pembelajaran IPA. 8(3B)

Eviani,dkk. 2014. Pengaruh Model Pembelajaran Berbasis Masalah Terhadap Kemampuan Literasi Sains IPA Kelas V SD. Jurnal Pendidikan. 3(7)

Hapsari, dkk. 2016. Pengembangan E-Modul Pengayaan Materi Pertumbuhan dan Perkembangan Untuk Meningkatkan Kemandirian dan Hasil Belajar. Jurnal Pendidikan Biologi. 5(5)

Hastuti, Woro. S. 2014. Peningkatan HOTS Calon Guru SD Melalui Penggunaan Discrepant Events Pada Aktifitas Saintifik Pembelajaran IPA Untuk Kesiapan Implementasi Kurikulum 2013. Prosiding Seminar Nasional Pemantapan Implementasi Kurikulum 2013 Dalam Pendidikan Sekolah Dasar. Universitas Negeri Yogyakarta.

Kemdikbud. 2017. Panduan Praktis Penyusunan E-Modul. Jakarta: Dirjendikdasmen PISA. 2016. PISA Resault and Focus. http://www.oecd.org. 5 Oktober 2017 (14.50).

Prastowo, Andi. 2013. Panduan Kreatif Membuat Bahan Ajar Inovatif. Yogyakarta: Diva Press

Sudarisman, Suciati. 2015. Memahami Hakikat dan Karakteristik Pembelajaran Biologi Dalam Upaya Menjawab Tantangan Abad 21 Serta Implementasi Kurikulum 2013. Jurnal Florea 2(1)

Wijayanti, dkk. 2016. Pengembangan E-Modul Berbasis Project Based Learning Pada Mata Pelajaran Simulasi Digital Untuk Siswa Kelas X Studi Kasus di SMK Negeri 2 Singaraja. Jurnal Pendidikan Teknologi dan Kejuruan 13(2) 